\title{
Family Signiphoridae (Chalcidoidea) in Egypt
}

\author{
S. ABD-RABOU'* and G. A. EVANS ${ }^{2}$ \\ ${ }^{1}$ Agricultural Research Center, Plant Protection Research Institute, 7 Nadi El-Seid, Giza, Egypt \\ ${ }^{2}$ USDA/APHIS/NIS, 10300 Baltimore Ave BARC-West, Bldg. 005, Rm. 09A, 20770. Beltsville, MD, USA
}

(Received: 7 July 2015; accepted: 29 October 2015)

\begin{abstract}
Species of the family Signiphoridae (Chalcidoidea) are primarily hyperparasitoids associated with scale insects, whiteflies and mealybugs through other Chalcidoidea; however, certain species are primary parasitoids of these hosts. Recent collections and a review of the literature indicate that the following five species of the family Signiphoridae are known to occur in Egypt: Chartocerus niger (Ashmead), Chartocerus subaeneus (Förster), Signiphora fax Girault, Thysanus sp. and Signiphora flavella Girault, the latter newly recorded in Egypt and Palearctic region. A key to the Egyptian signiphorid species is included.
\end{abstract}

Keywords: Signiphoridae, hyperparasitoids, hemipterous insects, biocontrol, Egypt.

The family Signiphoridae (Chalcidoidea: Hymenoptera) consists of 77 described species in four genera (Noyes, 2015). Most of the species belong to the genus Signiphora or Chartocerus with 40 and 32 species, respectively, and are worldwide in distribution; Thysanus has 4 species which are all native to the New World with 1 species (T. ater Walker) also recorded from Europe; and Clytina which has 1 species (C. giraudi Erdos) associated with Chloropidae (Diptera) in Europe and Central Asia. They are minute parasitic wasps, about $0.5-2 \mathrm{~mm}$ in length and usually black or brownish, sometimes with yellowish areas (mainly species in the genus Signiphora). The antennal flagellum is modified into 2-4 short, ring-like funicle segments (F1-F4) followed by a long unsegmented clava. The scutellum is narrow, more or less rectangular, about $5 \times$ wider than long. The mesonotal postphragma is very large, extending deeply into the gaster. The body is stout and flattened; the wings have a long marginal fringe and are devoid of setae, except for those on the veins and in the species which have a discal seta. Signiphorid species are primarily hyperparasitoids associated with scale insects including mealybugs (Coccoidea) or whiteflies (Aleyrodidae) through other Chalcidoidea, although some species have been recorded as primary parasitoids of mealybugs (Rozanov, 1965) and of armored scale insects. Most species are ectoparasitoids, although some are known to be endoparasitoids. Some species are also known to be primary ectoparasitoids in the puparia of the dipterous families Chamaemyiidae and Chloropidae.

The family has been treated taxonomically by several workers: Nikol'skaya (1950), Rozanov (1965), Hayat (1970 and 1976) and Hayat and Subba Rao (1986), Woolley

* Corresponding author; e-mail: shaabanabdrabou59@yahoo.com 
(1988, 1997) and Noyes (2003) and in Egypt by Abd-Rabou et al. (2001), Abd-Rabou (2006) and EI-Serwy et al. (2007).

\section{Materials and Methods}

Crops infested with armored scale insects (Diaspididae), soft scale insects (Coccidae), mealybugs (Pseudococcidae), whiteflies (Aleyrodidae) and psyllids (Psylloidea) were examined in the field, using a pocket lens during 2009-2014. Parts of plants from different crops were collected and placed separately in paper bags for further examination in the laboratory. Materials were kept in a well-ventilated container until the emergence of any parasitoids. The parasitoids were identified by examining adult specimens mounted on slides in Hoyers medium or glued to small cards according to the methods of Abd-Rabou (2002) and Noyes (1982), respectively.

\section{Results and Discussion}

The family Signiphoridae is represented by the following 5 species in Egypt: Chartocerus niger (Ashmead), Chartocerus subaeneus (Förter), Signiphora fax Girault, Signiphora flavella Girault (new record) and Thysanus sp.

\section{Chartocerus niger (Ashmead) (Fig. 4)}

Signiphora nigra Ashmead 1900: 410; Type. USA: District of Columbia, in USNM. Thysanus niger (Ashmead); Armitage 1923: 513.

Chartocerus niger (Ashmead); Rozanov 1965: 878; Woolley 1988: 492.

Signiphora argentina Brèthes 1913: 97; synonymy according to De Santis 1957: 114.

Diagnosis: Body black, antennal flagelleum brown-black, legs black with anterior and middle tibiae brownish, except for their tips and all tarsi white, wings with the basal half or more infuscate with the apical half or less hyaline (Girault, 1913). Marginal fringe of the fore wing is much shorter than the maximum width of the wing (about $0.25 \times$ or less) and slightly shorter than the longest marginal cilia of the posterior wings; submarginal vein with two setae, marginal vein with six long setae (M1-M6) and the stigmal vein bears one seta (S), (Girault, 1913); calcar of fore leg without a comb of fine setae and forewing with seta M6 present on marginal vein (Woolley, 1988); female antennal flagellum with 4 very short, ring-like funicle segments with F4 slightly longer; club (about $5 \times$ as long as wide) and with several linear sensillae; male antennal club about $4 \times$ as long as wide (Trjapitzin, 1978).

Distribution: Western Palearctic: France, Italy, North Africa, Russia, Spain; Neotropical: Antilles, Argentina, Bermuda, Brazil, Jamaica, Puerto Rico; Nearctic: USA (Noyes, 2015).

Hosts: Primary parasitoids of Coccidae: Coccus hesperidum, Saissetia oleae; Diaspididae: Chrysomphalus aonidum, Comstockiaspis perniciosa, Comstockiella sabalis, 

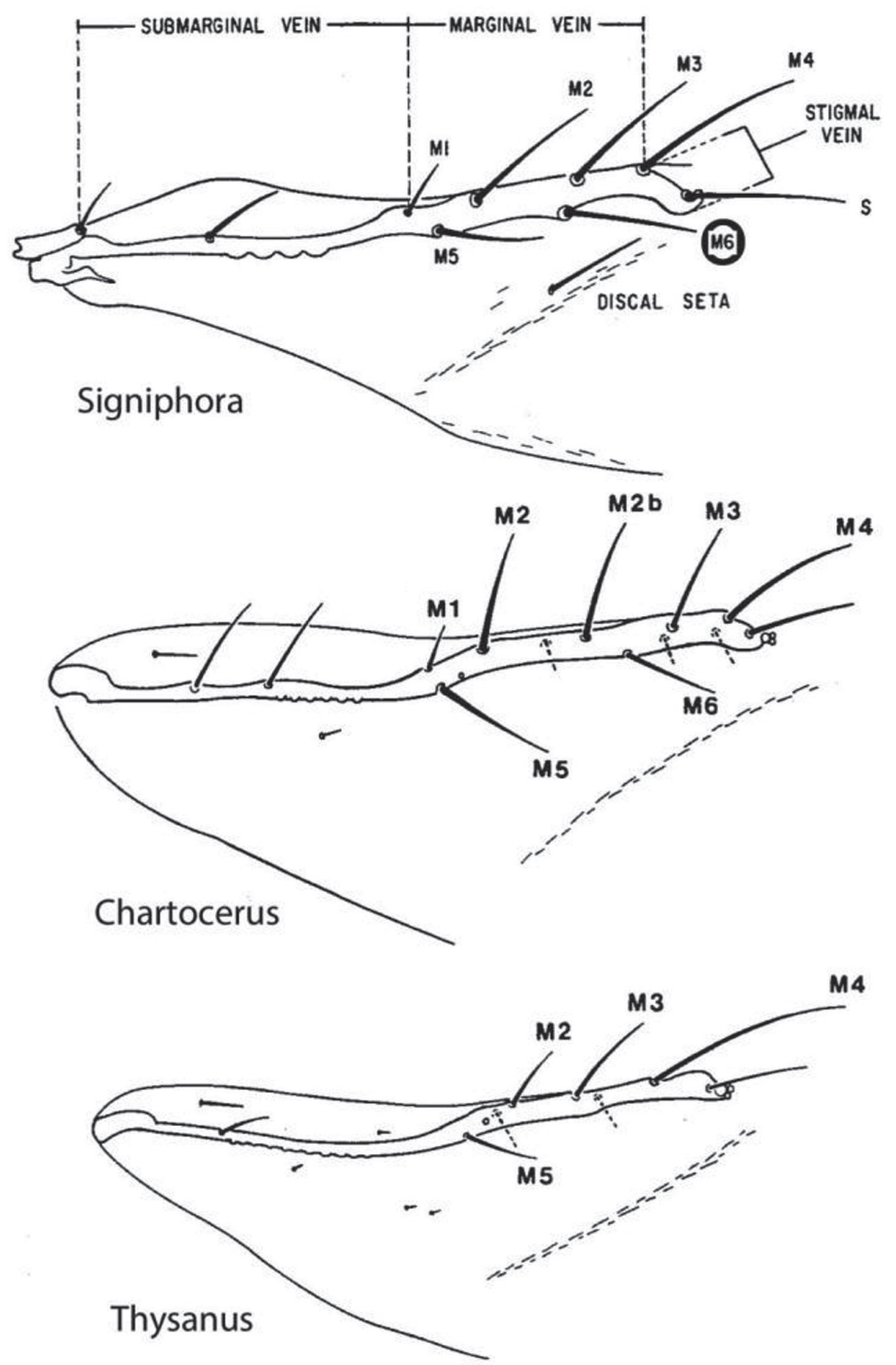

Fig. 1. Basal portion of forewings of signiphorid genera (after Woolley, 1988) with M6 seta circled in top illustration 
Diaspis boisduvalii; Pseudococcidae: Dysmicoccus brevipes, Phenacoccus gossypii, Planococcus citri, Pseudococcus comstocki, Pseudococcus longispinus (Noyes, 2015).

Material examined: 12QQ Q, Qalyubiya, 15. X. 2009, ex. Chrysomphalus aonidum (L.) (Hemiptera: Diaspididae) on Citrus sp. Also, collected from Alexandria and Behira governorates in September, 2005 from Hemiberlesia lataniae (Sign.) infested olive trees

Remarks: This species was recorded for first time in Egypt by Abd-Rabou (2006).

\section{Chartocerus subaeneus (Förster) (Fig. 3)}

Plastocerus subaenea Förster 1878: 69. Type. Germany, lectotype male designated by Rosen et al. 1992: 246.

Thysanus subaeneus (Förster); Dalla Torre 1898: 223.

Signiphorina subaenea (Förster); Nowitzky 1954: 207.

Chartocerus subaeneus (Förster); Rozanov 1965: 878; Trjapitzin 1978: 516; Woolley 1988: 492.

Signiphorina mala Nikol'skaya 1950; synonymy according to Nowitzky 1954: 207.

Chartocerus mala (Nikol'skaya); Xu and Huang 2004: 446.

Diagnosis: Body entirely black, antennae dark brown; antennae dark brown, eyes and ocelli black, all tarsi yellowish, fore tibiae pale, middle and hind tibiae black in proximal half and pale distally, other segments of legs black; calcar of fore leg without a comb of fine setae and forewing with seta M6 present on marginal vein; fore wing with alternating, broad hyaline and dark bands (Woolley, 1988). Longest marginal cilia 0.5-0.7 $\times$ maximum width of disc. Submarginal vein $0.75 \times$ to nearly as long as the marginal vein, bearing 2 setae and 13 bullae, marginal vein bearing 4 long setae along anterior margin and 4-5 short ventral setae, stigmal vein about $0.25 \times$ the length of the marginal vein and bearing a single seta and 3 discoid sensilla (Trjapitzin, 1978). Costal cell bearing a single dorsal seta. Adult male with medial denticles of its genitalia robust, curved and long, extending approximately half the length of the digiti and inserted on a strongly sclerotized region between the bases of the digiti; middle and hind tibiae black in proximal half (Rosen et al., 1992). Female antennal flagellum with 4 very short, ring-like funicle segments with F4 slightly longer; club (about $5 \times$ as long as wide) and with several linear sensillae; male antennal club more than $5 \times$ as long as wide (Trjapitzin, 1978).

Material examined: 10\%@, Behira, 17. XI. 2009, ex. Maconellicoccus hirsutus (Green) (Hemiptera: Pseudococcidae) on Hibiscus sp.

Remarks: This species is widespread in Europe (Noyes, 2015) and also has been recorded from Nigeria and Gambia (Neuenschwander et al., 1987) and China (Xu and Huang, 2004). It is primarily associated with various scale insect families and was recorded for first time in Egypt by Abd-Rabou (1999).

\section{Signiphora fax Girault (see Fig. 1 of S. flavopalliata forewing)}

Signiphora fax Girault 1913: 223. Type. Puerto Rico, San Juan, i. 1899, A. Busck, ex Mycetaspis personata on Mangifera indica and Annona muricata; also from Grenada and Barbados; in USNM; Woolley 1988: 494. 


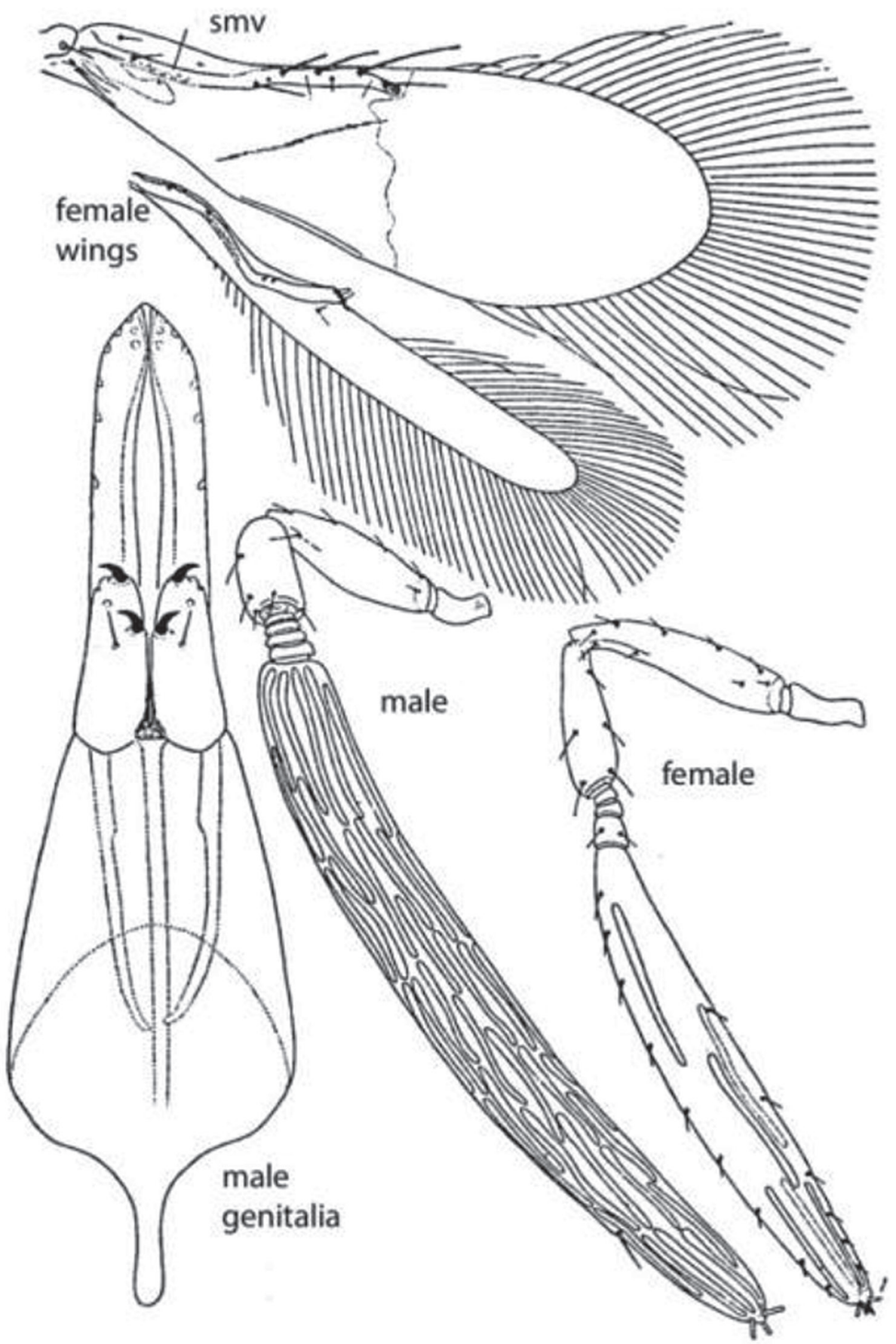

Fig. 2. Thysanus ater (after Rozanov, 1965) 


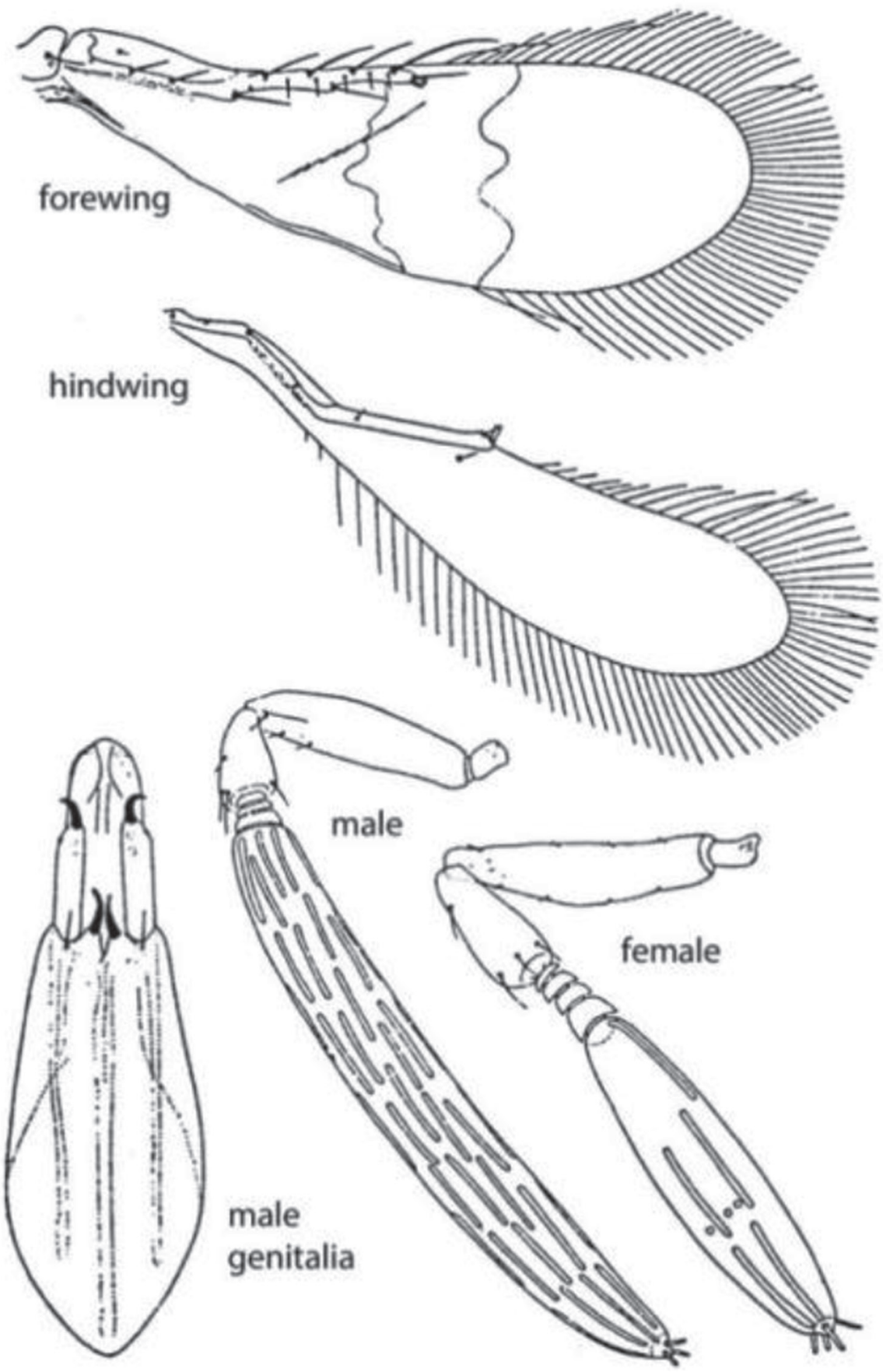

Fig. 3. Chartocerus subaeneus (after Rozanov, 1965) 

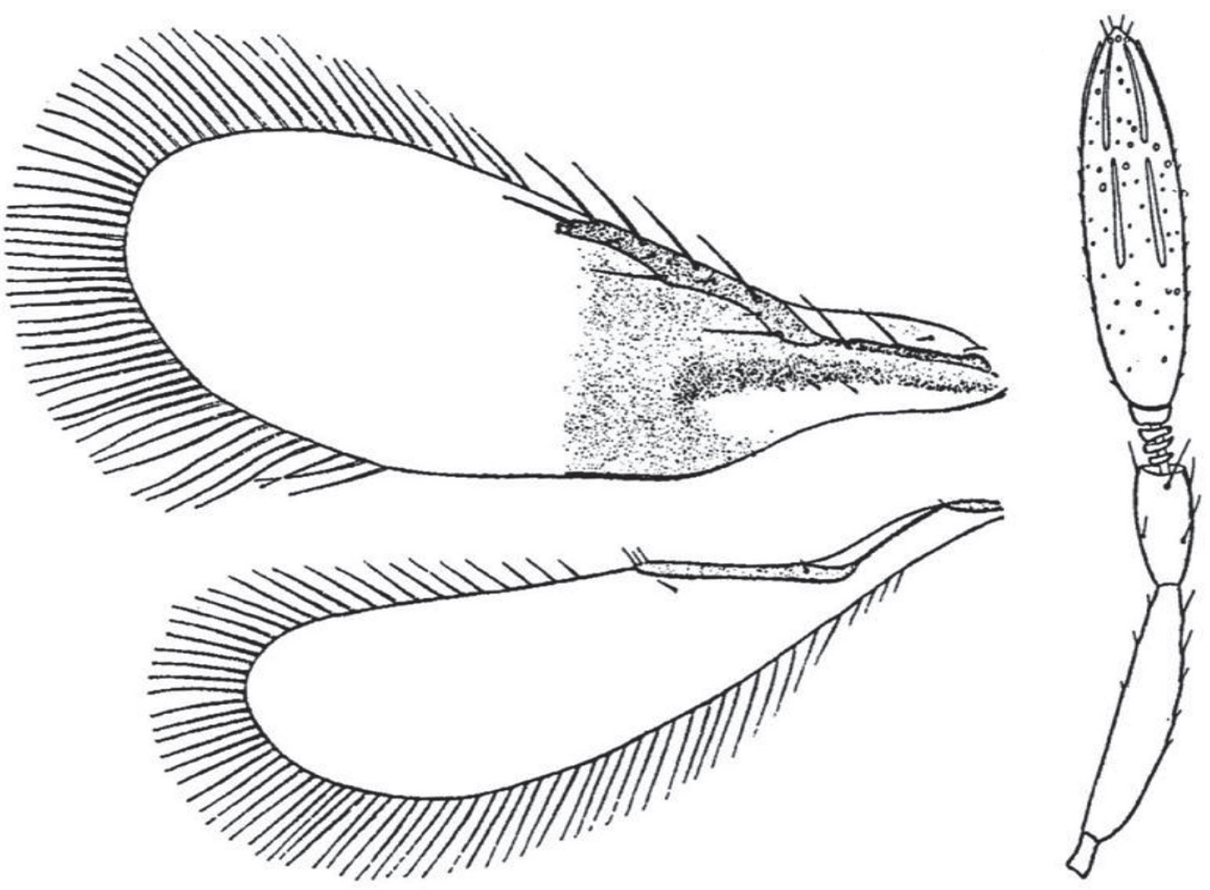

Fig. 4. Chartocerus niger. Female wings and antennae (after Smith and Compere, 1928)

Diagnosis: Forewing with a discal seta (Fig. 1); forewing submarginal vein with 1 seta; hind wing marginal vein with 2 setae (S. flavopalliata group); female dark brown with posterior third of mesoscutum, entire scutellum and propodeum yellow, lateral sclerites on each side of propodeum brown; fore wings with infuscate region extending to end of the venation. Scutellum usually with 4 setae (rarely 5-6); second tergite (T2) with posteriormedial margin rounded; calcar of fore leg with a comb of fine setae.

Material examined: Collected from Alexandria (North of Egypt) by Abd-Rabou et al. (2001).

Remark: This is a Neotropical species recorded from Argentina, Brazil, Puerto Rico and Uruguay associated primarily with armored scales (Diaspididae) but also has been recorded from Aleyrodidae, Coccidae and Pseudococcidae (Noyes, 2015). It was recorded in Egypt by Abd-Rabou et al. (2001).

\section{Signiphora flavella Girault (Fig. 5)}

Signiphora flavella Girault 1913: 214. Type. USA: Florida, Miami, 8.vi.1908, E.A. Bessey, ex. Hemiberlesia lataniae on Ochras sapota, in Illinois State Laboratory of Natural History, Urbana, Illinois, USA; Woolley 1988:494.

Thysanus flavellus (Girault); Peck 1951: 473.

Signiphora basilica Girault 1913: 215; synonymy according to Peck 1951: 473. 
Forewing without a discal seta; forewing submarginal vein with 1 seta; hind wing marginal vein with 2 setae (S. aleyrodis group); head orangish with dark, transverse oval area on clypeus between the antennal bases; antennal club tan, entirely dusky brown or dusky brown in distal quarter to half; female abdomen yellow to orange with basal half of gaster suffused with brownish area; posterior region of tergite II (T2, Fig. 5D) straight and transverse; scutellum usually with 6-7 setae (rarely 4-5); calcar of fore leg with a comb of fine setae.

Material examined: 3ọo, Ismailia, 13. XI. 2014, ex. Aonidiella aurantii (Hemiptera: Diaspididae) on Citrus sp.

Remarks: This species has been reported from Argentina, Australia, Chile, Cuba, Mexico, New Zealand and the United States and is associated primarily with armored scales but has also been reported on whiteflies (Aleyrodidae) and a pit scales (Asterolecaniidae) (Noyes, 2015). This is the first record of this species occurring in Egypt and the Western Paleactic region.

\section{Thysanus sp. (Fig. 4)}

Diagnosis: Body slender, elongate, occipital margin smoothly rounded, mandibles tridentate, female and male antenna with 4 short, anneliform funicle segments and elongate club, scape relatively short, less than $2 \times$ as long as pedicel; female club with a few elongate linear sensillae, male club covered with numerous elongate linear sensillae; forewing narrow, $3 \times$ longer than greatest width, submarginal vein with 1 seta, longest cilia of marginal fringe slightly shorter than greatest width of forewing disc; hindwing narrow, oar-like, its submarginal vein bearing 1 seta; tibiae of middle leg with spur about half as long as basitarsus II; calcar of fore leg without a comb of fine setae

Material examined: 5ǫ, Giza, 11.IV. 2009, ex. Pulvinaria tenuivalvata (Newstead) on sugar cane.

Hosts: Pulvinaria tenuivalvata (Hemiptera: Coccidae).

Remark: This species was recorded in Egypt by El-Serwy et al. (2007).

The genus Thysanus consists of four species and is probably native to the New World. It is likely that the species collected in Egypt is Thysanus ater Walker since it is the only species in the genus known to occur in the Western Palearctic region and is the only species in the genus associated with soft scale insects (Coccidae). Thysanus ater has a brownish-black body with with the base of the forewing infuscate;

\section{Key to the Signiphoridae species in Egypt}

1. Marginal vein of forewing without seta M6, occipital margin rounded; calcar of fore leg without comb of fine setae; middle femur with 1 large spine; antennae of male and female with 4 anelliform funicle segments; hindwing with parallel margins (Fig. 2)

Thysanus sp.

1b. Marginal vein of forewing with seta M6, occipital margin narrowly rounded or acute; shape of hindwing; remaining characters variable 
2. Calcar of fore tibia with a comb of fine setae; female antenna variable but usually with 3 anelli; middle femur with 1-2 long spines; body color variable but often with light coloration Signiphora $\mathrm{sp...3}$

2b. Calcar of fore tibia without a comb of fine setae; female antenna with 4 anelli, male antenna with 3 anelli; middle femur usually with 3-4 long spines; body entirely black or dark brown, lacking light coloration on thorax or abdomen

Chartocerus sp...4

3. Forewing without a discal seta; forewing submarginal vein with 1 seta; hind wing marginal vein with 2 setae ( $S$. aleyrodis group); antennal club tan, entirely dusky brown or dusky brown in distal quarter to half; female abdomen yellow to orange with basal half of gaster suffused with brownish area; clypeus with dark, transverse oval spot in contrast with orange head; scutellum usually with 6-7 setae (rarely 4-5); T2 with posteriormedial margin transverse (Fig. 5).

flavella Girault
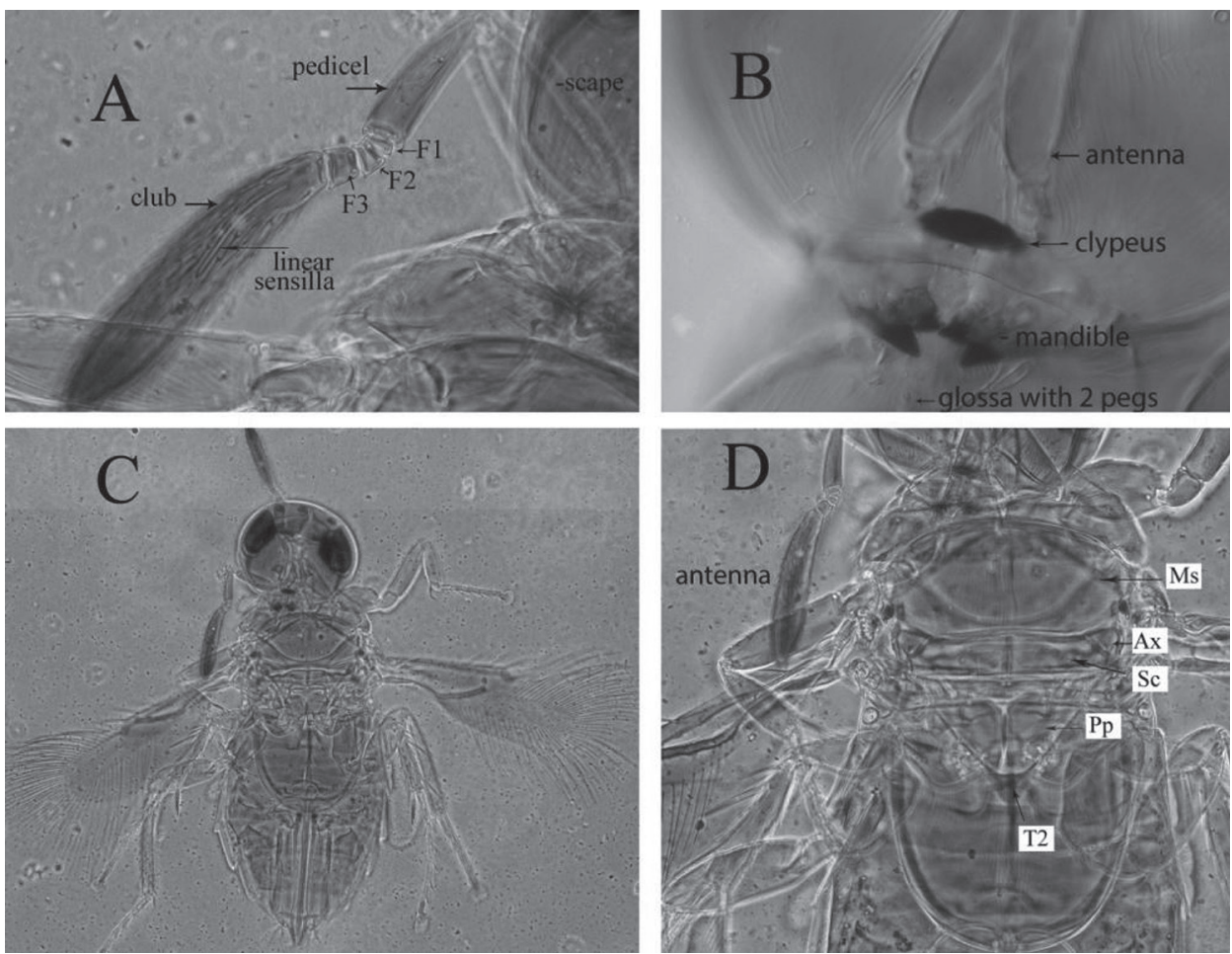

Fig. 5. Signiphora flavella. Female. A. Antenna, B. Head, C. Habitus, D. Thorax (Ms: mesoscutum; Ax: axilla, Sc: scutellum, Pp: propodeum, T2: tergite II) 
3b. Forewing with a discal seta (Fig. 1); forewing submarginal vein with 1 seta; hind wing marginal vein with 2 setae ( $S$. flavopalliata group); female dark brown with posterior third of mesoscutum and entire scutellum and propodeum yellow; scutellum usually with 4 setae (rarely 5-6); T2 with posteriormedial margin rounded .fax Girault

4. Forewing narrow, disk width about $0.8 \times$ disk length and $2.75 \times$ longer than longest marginal cilia, forewing dusky from base to just before juncture of stigmal vein; female antennal club short, about $3.4 \times$ longer than wide with a few linear sensillae; head, body and antennae black; legs, except tarsi black (tarsi brownish yellow, usually those of middle leg more pallid (Fig. 4) Chartocerus niger

4b. Forewing broader, disk width about $0.6 \times$ disk length and $2 \times$ longer than longest marginal cilia; female antennal club longer, about $4 \times$ longer than wide with a few linear sensillae; head, body black with bronze sheen (Fig. 3) Chartocerus subaeneus

\section{Literature}

Abd-Rabou, S. (1999): Seven species of superfamily Chalcidoidea (Hymenoptera) new to Egypt. J. Agric. Res. 77, 1205-1215.

Abd-Rabou, S. (2002): Revision of Aphelinidae (Hymenoptera) from Egypt. Second International Conference, Vol. of Plant Protection Research Institute, Vol. 1, 262-290.

Abd-Rabou, S. (2006): Hymenopterous parasitoids as a bioagent for controlling homopterous insects in Egypt. Egyptian Advances Agriculture Research In Egypt, Vol. 1, 1-65.

Abd-Rabou, S., Hanafi, A. and Hussein, N. (2001): Notes on the parasitoids of the soft brown scale, Coccus hesperidum (Hemiptera: Coccidae) in Egypt. Entomologica Bari, 33, 179-184.

Armitage, H. M. (1923): The present status of Aphycus lounsburyi How. in Southern California. J. Econ. Entomol. 16, 511-516.

Ashmead, W. H. (1900): On the genera of chalcid-flies belonging to the subfamily Encyrtinae. Proc. of the United States National Museum, 22, 323-412.

Brèthes, J. (1913): Himenópteros de la América meridional. Anales del Museo Nacional de Historia Natural de Buenos Aires, 24, 35-166.

Dalla Torre, K. W. von (1898): Catalogus Hymenopterorum hucusque descriptorum systematicus et synonymicus. V. Chalcididae et Proctotrupidae, 598 p.

De Santis, L. (1957): Anotaciones sobre calcidoideos Argentinos (Hymenoptera). Notas del Museo de La Plata, Buenos Aires (Zoologia), 19, 107-119.

El-Serwy, S. A., Guerrieri, E. and Evans, G. A. (2007): The parasitoid complex of the red-striped soft scale, Pulvinaria tenuivalvata (Newstead) (Hemiptera: Coccidae) and its long-term effect on the scale on sugarcane in Egypt Proc. of the XI. International Symposium on Scale Insect Studies, pp. 217-227.

Girault, A. A. (1913): A systematic monograph of the chalcidoid Hymenoptera of the subfamily Signiphorinae. Proc. of the United States National Museum, 45, 189-233.

Hayat, M. (1970): Studies on the genera of the family Signiphoridae (Hymenoptera: Chalcidoidea) recorded from India. Entomophaga 15, 396-398.

Hayat, M. (1976): Some Indian species of Chartocerus (Hym.: Chalcidoidea: Signiphoridae). Oriental Insects 10, 162.

Hayat, M. and Subba Rao, B. R. (1986): Family Signiphoridae. In: B. R. Subba Rao and M. Hayat (eds): The Chalcidoidea (Insecta: Hymenoptera) of India and the Adjacent Countries. Part II). Oriental Insects 20, 139-141.

Neuenschwander, P., Hennessey, R. D. and Herren, H. R. (1987): Food web of insects associated with the cassava mealybug, Phenacoccus manihoti Matile-Ferrero (Hemiptera: Pseudococcidae), and its introduced 
parasitoid, Epidinocarsis lopezi (De Santis) (Hymenoptera: Encyrtidae), in Africa. Bulletin of Entomological Research 77, 177-189.

Nikol'skaya, M. N. (1950): Representives of the family Signiphoridae [Hymenoptera: Chalcidoidea] in the fauna of the U.S.S.R. Dokl. Akad. Nauk. SSSR, 75, 319-320.

Nowitzky, S. (1954): Synonymy and distribution of Signiphorina subaenea Först. (Hym., Chalc., Thysanidae), a hyperparasite of mealybugs (Pseudococcus sp.). Bollettino di Zoologia Agraria e Bachicoltura, Milano, 20, 203-212.

Noyes, J. S. (1982): Collecting and preserving chalcid wasps (Hymenoptera: Chalcidoidea). J. Nat. Hist. 16, 315-334.

Noyes, J. S. (2003): Universal Chalcidoidea Database. World Wide Web electronic publication. www.nhm. ac.uk/entomology/chalcidoids/index.html.

Noyes, J. S. (2015): Universal Chalcidoidea Database. World Wide Web electronic publication. www.nhm. ac.uk/entomology/chalcidoids/index.html.

Peck, O. (1951): Superfamily Chalcidoidea. In: C. F. W. Muesebeck, K. V. Krombein and H. K. Townes (eds): Hymenoptera of America North of Mexico - Synoptic Catalog. Agriculture Monographs. U. S. Department of Agriculture, 2, 410-594.

Rosen, D., Argov, Y. and Woolley, J. B. (1992): Biological and taxonomic studies of Chartocerus subaeneus (Hymenoptera: Signiphoridae), a hyperparasite of mealybugs. J. Hymenoptera Research 1, 241-253.

Rozanov, I. V. (1965): Review of the genera of parasitic Hymenoptera of the family Signiphoridae (Hymenoptera: Chaleidoidea). Ent. Obozr, Moscow, 44, 866-884.

Smith, H. S. and Compere, H. (1928): A preliminary report on the insect parasites of the black scale, Saissetia oleae (Bernard). University of California Publications in Entomology 4, 231-334.

Trjapitzin, V. A. (1978): Hymenoptera II. Chalcidoidea 17. Signiphoridae. Opredeliteli Nasekomykh Evropeyskoy Chasti SSR, 3, 516.

Woolley, J. B. (1988): Phylogeny and classification of the Signiphoridae (Hymenoptera: Chalcidoidea). Systematic Entomol. 13, 465-501.

Woolley, J. B. (1997): Chapter 18. Signiphoridae. In: G. A. P. Gibson, J. T. Huber and J. B. Woolley (eds): Annotated Keys to the Genera of Nearctic Chalcidoidea (Hymenoptera). NRC Research Press, Ottawa, Ontario, Canada. pp. 693-699.

$\mathrm{Xu}, \mathrm{Z}$. H. and Huang, J. (2004): Chinese fauna of parasitic wasps on scale insects. National Natural Science Foundation of China, $524 \mathrm{p}$. 
